\title{
Pelatihan Konselor Sebaya Daring Untuk Meningkatkan Literasi Kesehatan Mental Siswa di SMA Islam XY Semarang
}

\section{Online Peer Counselor Training to Increase Mental Health Literacy among Students in Islamic Senior High School XY Semarang}

\author{
Diany Ufieta Syafitri ${ }^{1}$, Laily Rahmah ${ }^{2}$ \\ 1,2Fakultas Psikologi, Universitas Islam Sultan Agung
}

\begin{abstract}
The stage of adolescent development is a period full of changes, making it prone to psychological problems. Low mental health literacy also prevents adolescents from recognizing psychological problems and seeking appropriate help. Psychological services in schools are considered not adequate because of the limited resources available. Therefore, it is necessary to form peer counselors to utilize psychological services in schools. This study aimed to examine the effect of online peer counselor training in improving mental health literacy among students at Islamic Senior High School XY Semarang. In this training, participants were trained mental health literacy, that is the ability to recognize various mental health problems, various psychological help options available, and simple skills to help themselves and others. This study employed purposive sampling to determine 16 participants from grade XI-XII based on their involvement in school extracurricular activities. The study was conducted using one group pre and posttest quasi experiment design. Before and after the training, participants were given a mental health literacy scale. Using the paired sample $t$-test, results showed that after training, there was a significant difference in knowledge $(t=-3.162, p=0.006)$. In general, the results showed that online peer counselor training can improve participants' mental health literacy.
\end{abstract}

Keywords: adolescents; mental health literacy; online training; peer counselor

Abstrak. Masa remaja merupakan masa yang rentan terjadi masalah psikologis karena merupakan masa yang penuh perubahan. Literasi kesehatan mental yang rendah juga membuat para remaja terhambat dalam mengenali masalah psikologis yang dirasakan dan mencari bantuan yang tepat. Layanan psikologis di sekolah seringkali kurang maksimal karena keterbatasan sumber daya yang ada. Oleh karena itu perlu dibentuk konselor sebaya untuk memaksimalkan layanan psikologis di sekolah. Penelitian ini bertujuan untuk mengetahui pengaruh pelatihan konselor sebaya daring terhadap peningkatan literasi kesehatan mental pada siswa di SMA Islam XY Semarang. Pada pelatihan ini peserta diberi materi literasi kesehatan mental, yakni tentang mengenali berbagai masalah kesehatan mental, berbagai pilihan bantuan psikologis yang tersedia, dan keterampilan sederhana untuk menolong diri sendiri dan orang lain. Penelitian ini menggunakan sampling purposif di mana terdapat 16 siswa dari kelas XI-XII yang dipilih berdasarkan keaktifan dalam kegiatan ekstrakurikuler di sekolah. Penelitian ini dilakukan menggunakan desain kuasi eksperimen satu kelompok dengan pre dan postes. Sebelum dan setelah pelatihan, partisipan diberi skala literasi kesehatan mental dengan reliabilitas 0,747 . Analisis yang dilakukan menggunakan uji $\mathrm{t}$ berpasangan menunjukkan setelah pelatihan terdapat perbedaan pengetahuan $(t=-3,162 ; p=0,006)$. Secara umum hasil penelitian ini menunjukkan bahwa pelatihan konselor sebaya daring dapat meningkatkan literasi kesehatan mental partisipan.

Keywords: konselor sebaya; literasi kesehatan mental; pelatihan daring; remaja 
Tahap perkembangan remaja merupakan masa penuh peralihan yang menyebabkan seseorang rentan terhadap berbagai masalah psikologis. Menurut World Health Organization (WHO), kondisi kesehatan mental berkontribusi sebesar 16\% terhadap beban penyakit dan luka pada individu usia 10-19 tahun. Depresi merupakan penyebab pertama penyakit dan disabilitas pada remaja secara global, dan bunuh diri merupakan penyebab ketiga kematian pada usia 15-19 tahun (WHO, 2020). Hasil penelitian Kementerian Kesehatan, di Indonesia menunjukkan bahwa bahwa prevalensi depresi pada individu lebih dari 15 tahun adalah $6,1 \%$ dan gangguan mental emosional adalah 9,8\%, di mana dari jumlah tersebut hanya 9\% yang mendapatkan penanganan untuk gangguan depresi (Badan Penelitian dan Pengembangan Kesehatan Kementerian Kesehatan RI, 2018).

Onset terjadinya berbagai gangguan kesehatan mental pada masa remaja dimulai sejak usia 14 tahun tetapi kebanyakan kasus tidak terdeteksi apalagi tertangani secara maksimal (Kessler et al., 2007). Salah satu alasan kurangnya penanganan yang maksimal ini adalah karena adanya stigma yang dimiliki oleh remaja, rendahnya pengetahuan tentang permasalahan kesehatan mental (literasi kesehatan mental), dan keinginan untuk bergantung pada diri sendiri (Gulliver et al., 2010). Di sekolah sendiri, terutama di Indonesia, layanan psikologis yang tersedia dinilai masih kurang dapat memfasilitasi kebutuhan para siswa karena terbatasnya guru bimbingan konseling yang ada di setiap sekolah (Ridha, 2019). Oleh karena itu, diperlukan suatu program yang dapat menjangkau lebih banyak siswa yaitu melalui program konselor sebaya yang bertujuan untuk membantu teman yang mengalami permasalahan, sekaligus mensosialisasikan peran guru bimbingan konseling di sekolah (Salmiati et al., 2018).

SMA Islam XY, yang merupakan salah satu sekolah menengah swasta berbasis keagamaan di Kota Semarang, Jawa Tengah. Berbagai permasalahan psikologis dan akademis juga dialami oleh beberapa siswa di sekolah tersebut. Berdasarkan hasil wawancara terhadap beberapa siswa di sekolah tersebut didapatkan informasi bahwa permasalahan yang kerap terjadi adalah prestasi akademik siswa yang cenderung rendah (dapat dilihat dari peringkat sekolah yang rendah), banyak siswa yang mengalami gejala gangguan emosional (mudah marah, sensitif) dan menentang (oppositional defiant disorder) kepada orang dewasa (guru), banyak terjadi tindak perilaku bullying baik fisik, sosial, maupun verbal yang dilakukan antar siswa bahkan siswa kepada guru, dan beberapa siswa terlibat dalam kasus kenakalan remaja seperti balapan liar, merokok, dan minum-minuman keras (Siswa A, 2020). Hal ini juga diperkuat oleh hasil laporan magang mahasiswa Fakultas Psikologi Universitas Islam Sultan Agung di sekolah tersebut, yang menunjukkan adanya masalah baik akademis maupun psikologis pada beberapa siswa seperti disebutkan sebelumnya (Basoffi, 2018; Fitri, 2019).

Hasil wawancara dengan guru Bimbingan Konseling (BK) terkait masalah psikologis yang dialami siswa-siswa SMA Islam XY adalah kurangnya guru BK untuk menangani para siswa yang ada padahal setiap bulannya para guru BK setidaknya menangani sekitar 10 siswa yang melanggar peraturan baik akademis maupun non akademis seperti dijelaskan di atas. Penanganan yang diberikan kepada para siswa tersebut adalah memanggil para siswa 
yang dianggap bermasalah, memberikan nasihat, dan terkadang memanggil para orangtua siswa (Guru Bimbingan Konseling, 2020). Meskipun demikian, menurut hasil wawancara dengan wakil kepala sekolah, penanganan tersebut dinilai belum maksimal karena hanya diberikan pada siswa yang telah melakukan pelanggaran, tidak bisa menjangkau semua siswa akibat terbatasnya personil, dan belum merupakan upaya untuk mencegah atau mendeteksi secara dini permasalahan yang dialami siswa (Wakil Kepala Sekolah, 2020). Berdasarkan hasil wawancara tersebut, pihak sekolah mengharapkan adanya suatu program yang dapat menjangkau lebih banyak siswa dan bersifat mencegah terjadinya permasalahan psikologis yang lebih berat.

Seperti sudah disinggung di atas, salah satu program yang dipercaya dapat memaksimalkan layanan kesehatan mental di sekolah adalah program konselor sebaya (Ridha, 2019). Menurut Gray dan Tindall (1979), konseling teman sebaya adalah proses membantu secara interpersonal yang dilakukan oleh seorang nonprofesional kepada teman sebayanya, di bawah bimbingan seorang konselor profesional. Bagi remaja, konselor sebaya lebih dipilih dan diterima untuk mendiskusikan hal-hal yang dianggap sensitif seperti masalah seksualitas dan masalah pribadi lainnya karena peran teman sebaya sangat penting pada tahap perkembangan tersebut (Abdi \& Simbar, 2013). Konselor sebaya tidak ditujukan untuk menggantikan peran dan fungsi konselor profesional, tetapi menjadi penjembatan antara remaja dengan bantuan psikologis profesional, sehingga nantinya diharapkan konselor sebaya dapat menyarankan teman yang membutuhkan bantuan untuk berkonsultasi langsung kepada konselor professional (Suwarjo, 2008). Tidak hanya itu, dengan adanya konselor sebaya ini, sangat mungkin terjadi kontak yang spontan dan informal dengan teman-temannya sehingga memungkinkan terjadinya dampak yang besar pada para siswa di sekolah (Tindall, 2009). Harapannya dengan adanya konselor sebaya di SMA Islam XY dapat membantu pihak sekolah untuk menjangkau lebih banyak siswa yang memiliki permasalahan dan mendeteksi secara dini masalah yang terjadi.

Literasi kesehatan mental sendiri merupakan satu konstrak multi dimensi yang menggambarkan secara menyeluruh kemampuan seseorang dalam mengenali masalah psikologis dan melakukan pertolongan psikologis ringan (Kelly et al., 2007). Jorm (2012) mendefinisikan literasi kesehatan mental sebagai a) pengetahuan tentang bagaimana mencegah gangguan jiwa, (b) pengetahuan tentang gejala berbagai gangguan jiwa, (c) pengetahuan tentang pilihan pencarian bantuan dan penanganan yang tersedia, (d) pengetahuan strategi menolong diri sendiri untuk permasalahan yang ringan, dan (e) keterampilan pertolongan pertama untuk membantu orang lain yang mengalami gangguan jiwa/fisik. Siswa-siswa yang diberi pelatihan konselor sebaya diharapkan nantinya dapat mengenali berbagai jenis gangguan jiwa yang umum terjadi pada remaja, mengetahui pilihan pencarian bantuan yang tersedia baik untuk diri sendiri maupun orang lain, dan mampu memberikan pertolongan pertama.

Hasil penelitian menunjukkan bahwa ada hubungan yang erat antara literasi kesehatan mental dan masalah psikologis yang dialami remaja, di mana rendahnya literasi kesehatan mental membuat seseorang sulit mendeteksi masalah psikologis yang ia alami 
sehingga ia tidak tahu ke mana harus meminta pertolongan, selain itu adanya stigma dan sikap yang negatif terhadap bantuan psikologis professional sehingga niatan untuk mencari bantuan psikologis cenderung rendah (10-26\%) (Reavley et al., 2012). Oleh karena itu, peningkatan literasi kesehatan mental merupakan strategi untuk intervensi awal permasalahan psikologis di berbagai konteks, yang salah satunya melalui pelatihan berbasis sekolah yang mengajarkan keterampilan menolong diri sendiri maupun orang lain (Kelly et al., 2007). Penelitian yang lain menunjukkan bahwa mahasiswa dan siswa SMA di Inggris yang mengikuti program peer-led mental health literacy menunjukkan peningkatan yang signifikan pada pengetahuan tentang kesehatan mental, stigma yang lebih rendah terhadap kesehatan mental, dan peningkatan perilaku menolong (Patalay et al., 2017). Penelitian yang dilakukan di Portugal menunjukkan program berbasis sekolah jangka pendek mampu secara efektif meningkatkan literasi kesehatan mental para siswa (Campos et al., 2018). Berbagai penelitian di Indonesia juga menunjukkan keberhasilan program konselor sebaya untuk meningkatkan keterampilan dasar konseling pada siswa di SMA maupun panti sosial (Astiti, 2019; Rahmawati et al., 2019; Risnawaty et al., 2019; Titisari et al., 2019; Zamroni \& Masturi, 2017). Penelitian Al-Masyhida (2017) menggunakan modul pelatihan S3EHATI untuk meningkatkan literasi kesehatan jiwa dan keterampilan konseling dasar bagi para calon konselor sebaya pada siswa SMA di Yogyakarta menunjukkan bahwa modul tersebut mampu meningkatkan pengetahuan kesehatan jiwa secara signifikan. Hasil penelitian juga menunjukkan bahwa literasi kesehatan mental merupakan prediktor positif yang signifikan terhadap rujukan teman sebaya ke pusat konseling (Kalkbrenner et al., 2020) dan dapat memprediksi intensi mencari bantuan dari tenaga profesional (Paul et al., 2017; Smith \& Shochet, 2011).

Seperti kita ketahui pandemi COVID-19 yang saat ini melanda Indonesia telah mengubah metode belajar mengajar di Indonesia menjadi daring, di mana pembelajaran daring ini menjadi alternatif utama pelaksanaan pendidikan saat ini di semua tingkatan pendidikan (Setiawan et al., 2019). Perubahan metode ini tentunya memiliki kekurangan sehingga menjadi kesempatan untuk pengembangan metode belajar daring yang baru (Adedoyin \& Soykan, 2020; Dhawan, 2020). Oleh karena itu, berbeda dengan pelatihan yang telah ada sebelumnya, pelatihan konselor sebaya ini dilaksanakan secara daring.

Secara umum, terjadi perdebatan dalam pelaksanaan pendidikan secara daring karena efektivitasnya masih dipertanyakan dan terdapat beberapa hambatan dalam metode ini yang dianggap tidak bisa menyamai pendidikan secara luring (Bell \& Federman, 2013). Terlebih dalam pelatihan konseling, terdapat keraguan akan efektivitas pelatihan konselor yang dilakukan secara daring. Meskipun demikian, hasil penelitian Murdock et al. (2012) menunjukkan bahwa tidak ada perbedaan signifikan pada keterampilan konseling yang dimiliki oleh peserta pelatihan konselor baik secara daring maupun luring. Lebih lanjut, penelitian Roth et al. (2019) menunjukkan bahwa mahasiswa pendidikan konseling yang dilakukan secara daring di Amerika Serikat sebagian besar puas dengan pengalaman pendidikannya. Tidak hanya pada pelatihan konseling, program pelatihan daring yang dilakukan untuk meningkatkan kemampuan profesional kesehatan dalam menangani 
gangguan makan juga menunjukkan bahwa pelatihan yang dilakukan secara daring mampu meningkatkan pengetahuan, kepercayaan diri, keterampilan dalam menangani klien secara signifikan (Maguire et al., 2019).

Berdasarkan pemaparan di atas, dapat dilihat bahwa remaja merupakan masa yang rentan akan berbagai masalah psikologis. Namun demikian, hal ini tidak diimbangi dengan layanan psikologis berbasis sekolah yang memadai akibat kurangnya guru BK dan konselor profesional. Oleh karena itu, dibutuhkan program konselor sebaya untuk meningkatkan layanan psikologis melalui para siswa yang dipilih dan dilatih literasi kesehatan mental agar dapat mengidentifikasi gangguan psikologis yang umum pada remaja, dan mengetahui cara menolong diri sendiri maupun orang lain saat mengalami masalah psikologis tertentu. Harapannya, para konselor sebaya ini nantinya dapat menjembatani antara siswa yang mengalami masalah dengan guru BK maupun profesional kesehatan mental lainnya. Program konselor sebaya sudah banyak dilakukan baik di Indonesia maupun negara lain. Namun karena terjadi pandemi COVID-19, program tersebut perlu diubah menjadi bentuk daring karena ditutupnya sekolah tatap muka. Oleh karena itu, penelitian ini berupaya untuk mengetahui pengaruh pelatihan konselor sebaya yang dilakukan secara daring terhadap literasi kesehatan mental partisipan. Hipotesis dalam penelitian ini adalah ada pengaruh pelatihan konselor sebaya terhadap peningkatan literasi kesehatan mental partisipan, di mana partisipan yang mendapat pelatihan konselor sebaya menunjukkan literasi kesehatan mental yang secara signifikan lebih tinggi setelah mengikuti pelatihan.

\section{Metode}

Penelitian ini dilakukan dengan metode eksperimen kuasi dengan desain satu kelompok pre dan postes. Variabel dependen dalam penelitian ini adalah literasi kesehatan mental, sedangkan variabel independennya adalah pelatihan konselor sebaya daring.

Pelatihan konselor sebaya dalam penelitian ini mengadaptasi dari beberapa modul yang telah ada, yaitu modul Pelatihan S3EHATI yang disusun oleh Al-Masyhida (2017) untuk meningkatkan literasi kesehatan mental dan keterampilan konseling dasar pada siswa SMA di Yogyakarta. Selain itu, pelatihan ini juga mengadaptasi dari modul yang disediakan oleh mhlcurriculum.org sebuah Lembaga di Amerika Serikat yang menyusun modul pelatihan literasi kesehatan mental dan konseling sebaya.

Menurut Marks et al. (2005) terdapat tiga aspek yang mempengaruhi efektivitas pembelajaran daring, yaitu interaksi antara instruktur-peserta, peserta-peserta, dan pesertakonten. Aspek peserta-konten menunjukkan bahwa diperlukan peralatan yang bervariasi (tayangan Power Point, video, dan lain-lain). Hal ini juga didukung oleh penelitian Gaytan dan McEwen (2007) yang menyatakan perlunya variasi metode instruksi. Oleh karena itu, meskipun dilaksanakan secara daring, pelatihan ini berusaha untuk memvariasikan metode instruksi dengan media penyampaian yang menarik, mengupayakan interaksi dengan peserta melalui menti.com, kotak chat, video, permainan sederhana, bermain peran, dan penugasan. 
Gambaran materi Pelatihan Konselor sebaya ini di setiap pertemuan adalah 1) perkembangan psikologis remaja, masalah kesehatan mental yang biasa dialami remaja, pengertian konselor sebaya dan urgensinya, 2) mengenal berbagai gangguan kesehatan mental remaja bagian 1 (mitos dan fakta terkait gangguan kesehatan mental, mengenal gangguan mood), 3) mengenal berbagai gangguan kesehatan mental remaja bagian 2 (gangguan kecemasan, kecanduan, perilaku menyakiti diri, bunuh diri, penyebab gangguan kesehatan mental, dan diagnosisnya), 4) mencari bantuan untuk diri sendiri, dan 5) menolong orang lain (keterampilan dasar konseling) dan roleplay konseling.

\section{Partisipan penelitian}

Partisipan dalam penelitian ini ditentukan melalui purposive sampling dengan kriteria sebagai berikut: 1) siswa aktif di SMA Islam XY kelas XI-XII (kelas X tidak diikutkan mempertimbangkan siswa kelas $X$ belum pernah merasakan sekolah tatap muka selama pandemi COVID-19 sehingga belum mengenal lingkungan sekolah secara maksimal); 2) aktif dalam kegiatan organisasi ekstrakurikuler sekolah (OSIS, Pramuka, dan lain sebagainya); 3) secara kognitif mampu memahami materi yang nantinya diberikan dalam pelatihan, yaitu dilihat dari kemampuan memahami materi pelajaran dan nilai di kelas; 4) bersedia meluangkan waktu untuk mengikuti pelatihan. Berdasarkan kriteria tersebut, pihak sekolah memilihkan 20 siswa yang sesuai dengan kriteria dan dianggap mampu mengikuti pelatihan ini. Alasan pemilihan tersebut adalah siswa yang aktif dalam kegiatan organisasi dianggap memiliki jaringan sosial yang luas sehingga harapannya bisa memberikan pengaruh lebih luas.

\section{Instrumen Pengumpulan Data}

\section{Literasi Kesehatan Mental}

Skala ini dibuat sendiri oleh peneliti, terdiri atas 17 pertanyaan dengan format jawaban benar-salah, yang mengukur pengetahuan peserta tentang 1) perubahan fisik dan psikologis di masa remaja, 2) berbagai gangguan psikologis pada masa remaja, 3) keterampilan dasar menolong orang lain (konseling). Kuesioner ini sebelumnya telah diujicobakan pada 46 siswa kelas XI -XII di SMA Islam XY (yang tidak mengikuti pelatihan) dan memiliki koefisien reliabilitas Alpha Cronbach 0,747.

\section{Lembar Observasi Keterampilan Konseling Daring}

Tujuan dari observasi keterampilan konseling daring ini adalah untuk mengetahui seberapa jauh peserta dapat menerapkan keterampilan konseling dasar sebagai bagian dari literasi kesehatan mental. Lembar panduan observasi ini diisi oleh fasilitator yang terdiri atas dua aspek yaitu ketepatan nada bicara dan mengikuti pembicaraan yang diadaptasi dari (Almasyhida, 2017). Aslinya terdapat empat keterampilan yang diamati dalam lembar observasi tersebut yaitu kontak mata, gesture tubuh, ketepatan nada bicara, dan mengikuti pembicaraan. Namun karena dilakukan secara daring, maka yang dapat diamati hanyalah 
nada bicara dan mengikuti pembicaraan sementara observasi terhadap kontak mata dan gesture tubuh tidak memungkinkan dilakukan.

\section{Kuesioner Evaluasi Setelah Pelatihan}

Kuesioner ini bertujuan untuk mengetahui respon peserta terhadap pelatihan yang baru saja diikuti terkait, terutama terkait apakah penyampaian dengan metode daring dapat diterima oleh peserta, beserta hambatan yang dirasakan. Kuesioner ini terdiri atas beberapa pertanyaan yang dijawab dengan memberikan skor 1-5, di mana skor satu menunjukkan nilai rendah suatu atribut dan skor lima menunjukkan nilai tinggi. Pertanyaan dalam kuesioner ini adalah terkait 1) seberapa besar motivasi peserta mengikuti pelatihan ini, 2) manfaat pelatihan yang dirasakan, 3) seberapa besar materi yang diserap, 3) seberapa besar perubahah pengetahuan tentang gangguan psikologis sebelum dan sesudah pelatihan yang dipersepsi partisipan, 4) seberapa besar peningkatan pengetahuan cara menolong diri sendiri dan orang lain sebelum dan sesudah pelatihan yang dipersepsi partisipan. Selain itu, peserta juga ditanyai tentang hambatan yang dirasakan selama pelatihan, hal-hal yang dipelajari selama pelatihan, dan masukan terhadap pelaksanaan pelatihan ini.

\section{Prosedur pelaksanaan penelitian}

Prosedur penelitian ini diawali dengan asesmen awal pada siswa, guru BK, dan Wakil Kepala Sekolah. Setelahnya dilanjutkan dengan koordinasi dengan pihak sekolah (Kepala Sekolah dan Wakil Kepala Sekolah Bidang Kurikulum) terkait pelaksanaan pelatihan. Wakil Kepala Sekolah kemudian menentukan siswa yang akan diikutkan sesuai kriteria yang diberikan peneliti. Setelah terkumpul 20 peserta yang dipilih oleh Wakil Kepala Sekolah dan terbentuk grup WhatsApp, peneliti memberikan informed consent kepada 20 peserta melalui google forms yang menjelaskan gambaran pelatihan yang akan diikuti, termasuk keuntungan dan kerugian yang mungkin dialami. Kegiatan dilanjutkan dengan peneliti berkenalan dan membangun rapport dengan para peserta yang telah mengisi informed consent melalui grup WhatsApp serta membuat komitmen untuk mengikuti pelatihan (menentukan jadwal dan teknis pelaksanaan). Sebelum pelaksanaan pelatihan pertemuan pertama dilaksanakan, peserta diberi pretes dengan skala Literasi Kesehatan Mental melalui google forms diberikan. Pelaksanaan pelatihan sebanyak lima kali pertemuan melalui Kegiatan pelatihan ini dilaksanakan secara daring melalui platform Zoom Meeting pada setiap hari Senin, Rabu, dan Jumat pada pukul 14:00-16:00. Setelah kegiatan pelatihan selesai, dilaksanakan postes dengan alat ukur yang sama dengan pretes, ditambah form evaluasi pelatihan melalui Google Forms.

\section{Hasil}

\section{Partisipan pelatihan}

Dari 20 peserta yang dipilih mengikuti pelatihan ini, empat orang mengundurkan diri sebelum pelatihan dilaksanakan karena alasan lokasi peserta yang tidak memiliki jaringan 
internet stabil dan bertabrakan dengan kegiatan lain, sehingga hanya 16 orang yang mengikuti hingga akhir.

Tabel 1.

Partisipan Pelatihan dan Deskripsi Skor Pre dan Postes

\begin{tabular}{ccccccc}
\hline No & Nama & Kelas & Usia (tahun) & Jenis Kelamin & $\begin{array}{c}\text { Literasi } \\
\text { Kesehatan } \\
\text { Mental-Pre }\end{array}$ & $\begin{array}{c}\text { Literasi } \\
\text { Kesehatan } \\
\text { Mental-Pos }\end{array}$ \\
\hline 1 & MMF & XI MIPA & 16 & Laki-laki & 11 & 14 \\
2 & SF & XI MIPA & 17 & Perempuan & 14 & 12 \\
3 & NA & XI MIPA & 16 & Perempuan & 14 & 15 \\
4 & AZF & XI MIPA & 15 & Perempuan & 14 & 17 \\
5 & IFH & XII MIPA & 17 & Laki-laki & 15 & 17 \\
6 & HBN & XI MIPA & 16 & Perempuan & 13 & 15 \\
7 & DS & XII IPS & 18 & Perempuan & 13 & 14 \\
8 & WCA & XI MIPA & 16 & Perempuan & 12 & 13 \\
9 & RAS & XII IPS & 17 & Perempuan & 15 & 17 \\
10 & WUR & XII MIPA & 17 & Laki-laki & 13 & 13 \\
11 & MSS & XI MIPA & 16 & Perempuan & 15 & 15 \\
12 & NFA & XI MIPA & 16 & Perempuan & 13 & 15 \\
13 & AAS & XII MIPA & 16 & Perempuan & 17 & 17 \\
14 & ET & XI MIPA & 17 & Perempuan & 14 & 15 \\
15 & ANP & XI IPS & 16 & Perempuan & 12 & 12 \\
16 & NP & XI IPS & 15 & Perempuan & 11 & 11 \\
& & & & Mean & 13,5 & 14,5 \\
& & & & SD & 1,6 & 1,9 \\
\hline
\end{tabular}

Tabel 2.

Hasil Observasi Keterampilan Konseling Dasar

\begin{tabular}{|c|c|c|}
\hline $\begin{array}{l}\text { Kategori Keterampilan } \\
\text { Konseling Dasar }\end{array}$ & Nama & Hasil Observasi \\
\hline \multirow{3}{*}{ Cukup baik } & MMF & $\begin{array}{l}\text { Serius, mampu menyampaikan empati dengan cukup } \\
\text { baik, meskipun terkesan santai saat berperan sebagai } \\
\text { konselor }\end{array}$ \\
\hline & NA & $\begin{array}{l}\text { Cukup mampu mempraktikkan keterampilan } \\
\text { konseling seperti empati, menyesuaikan intonasi } \\
\text { suara, dan mengikuti pembicaraan }\end{array}$ \\
\hline & $\mathrm{AZF}$ & $\begin{array}{l}\text { Cukup mampu mempraktikkan keterampilan } \\
\text { konseling, nada bicara tidak monoton, tidak terkesan } \\
\text { malu-malu, dan memberikan respon yang tepat saat }\end{array}$ \\
\hline
\end{tabular}




ditanya
RAS $\begin{aligned} & \text { Cukup mampu menyesuaikan intonasi suara dengan } \\ & \text { cerita klien dan mengikuti pembicaraan }\end{aligned}$
MSS $\begin{aligned} & \text { Cukup mampu mempraktikkan keterampilan } \\ & \text { konseling, nada bicara sesuai dengan cerita klien }\end{aligned}$
WUR $\begin{aligned} & \text { Sedikit terkesan main-main, tetapi bersedia } \\ & \text { mendengarkan klien dan memberikan jawaban }\end{aligned}$
AAS $\begin{aligned} & \text { dengan lawan bicaranya. Nada bicara dan intonasinya } \\ & \text { sudah seperti benar-benar siap mendengarkan. }\end{aligned}$
ET $\begin{aligned} & \text { Nada bicara tidak monoton, tidak terkesan malu- } \\ & \text { malu, tetapi kurang responsif ketika diberi }\end{aligned}$
pertanyaan
Cukup luwes, intonasi bicara dan cara
mengungkapkan empati cukup baik

Perlu pengembangan

Tidak bisa praktik secara langsung karena kendala

NFA jaringan internet sehingga dilakukan lewat kotak chat di Zoom Meeting

Tidak bisa praktik langsung karena kendala jaringan

Tidak bisa praktik karena

ANP internet, mengamati teman-teman praktik. Praktik kendala jaringan melalui kotak chat di Zoom Meeting.

Tidak mengikuti praktik langsung karena kendala jaringan internet, jadi hanya mengamati temantemannya yang praktik. Praktik dilakukan melalui kotak chat di Zoom Meeting

\section{Hasil kuesioner evaluasi setelah pelatihan}

Pada kuesioner ini terdapat tujuh pertanyaan dengan rentang jawaban 1-5, di mana semakin tinggi skor maka semakin tinggi atribut yang diukur. Hasil dari kuesioner evaluasi tersebut adalah 1) rerata motivasi mengikuti pelatihan adalah 4,3 yang berarti motivasi peserta untuk mengikuti pelatihan ini tinggi, 2) pada persepsi seberapa besar pelatihan bermanfaat 
didapatkan rerata 4,7 yang berarti pelatihan ini dinilai sangat bermanfaat, 3) terkait seberapa besar materi yang dapat diserap, didapatkan rerata 4,3 yang artinya sebagian besar materi dapat diserap dengan baik oleh peserta, 4) pertanyaan selanjutnya adalah terkait seberapa besar peserta memiliki pengetahuan tentang kesehatan mental sebelum dan sesudah pelatihan, di mana rerata sebelum mengikuti pelatihan adalah 2,1 dan setelah mengikuti pelatihan adalah 4,4 yang artinya peserta mempersepsi adanya peningkatan pengetahuan mereka sebelum dan sesudah mengikuti pelatihan, 5) dua pertanyaan terakhir adalah persepsi peserta terkait pengetahuan menolong diri sendiri dan orang lain sebelum dan sesudah pelatihan, di mana sebelum pelatihan reratanya 2,9 dan sesudah pelatihan adalah 4,6 yang artinya peserta mempersepsi adanya peningkatan pengetahuan cara menolong diri sendiri maupun orang lain setelah pelatihan.

Hambatan yang dirasakan oleh peserta selama pelatihan sebagian besar adalah masalah koneksi internet yang tidak stabil (8 orang), waktu pelatihan bersamaan dengan kegiatan lain seperti membantu orangtua dan mengerjakan tugas ( 5 orang), dan tidak ada hambatan apapun (3 orang).

\section{Uji prasyarat}

Uji normalitas data

Hasil uji normalitas menggunakan Kolmogorov Smirnov-Z didapatkan hasil sesuai penjelasan di tabel 3.

Tabel 3.

Hasil Uji Normalitas Data

\begin{tabular}{cccc}
\hline Variabel & KS-Z & $p$ & Keterangan \\
\hline $\begin{array}{c}\text { Pretes Skala Literasi } \\
\text { Kesehatan Mental } \\
\begin{array}{c}\text { Postes Skala Literasi } \\
\text { Kesehatan Mental }\end{array}\end{array}$ & 0,127 & 0,200 & Normal \\
\hline
\end{tabular}

\section{Hasil Analisis Paired t-test}

Berdasarkan hasil uji normalitas menggunakan Kolmogorov Smirnov-Z didapatkan bahwa semua data terdistribusi normal sehingga dapat dilanjutkan menggunakan analisis parametrik uji t berpasangan, yaitu dari Tabel 1 dapat dilihat bahwa rerata untuk pretes adalah 13,5 dan postes 14,5 dan hampir semua partisipan mengalami kenaikan skor kecuali 1 orang. Dari hasil uji $t$ berpasangan didapatkan hasil $t=-3,038$ dengan $p=0,008$ ( $\mathrm{p}<0,05)$ yang artinya terdapat perbedaan signifikan antara skor skala literasi kesehatan mental pada sebelum dan sesudah pelatihan.

\section{Pembahasan}


Penelitian ini bertujuan untuk mengetahui pengaruh pelatihan konselor sebaya yang dilakukan secara daring terhadap literasi kesehatan mental. Dalam prosesnya, terdapat beberapa hambatan dalam pelaksanaannya. Pertama karena tim peneliti maupun fasilitator dan peserta tidak pernah bertemu secara tatap muka langsung, hambatan yang utama adalah kesulitan saat membangun rapport di awal pertemuan. Kedua, hambatan teknis terkait jaringan internet yang tidak sama pada semua peserta membuat beberapa peserta keluar masuk Zoom Meeting dan empat peserta tidak bisa melakukan roleplay konseling secara langsung. Hal ini juga dapat dilihat pada hasil kuesioner evaluasi setelah pelatihan, di mana sebagian besar peserta (8 orang) menganggap konseksi internet sebagai hambatan dalam mengikuti pelatihan ini. Ketiga, sulitnya pengawasan terhadap peserta di mana fasilitator dan observer tidak bisa melihat langsung respon peserta saat materi diberikan. Berbagai hambatan yang dialami adalah terkait dengan pelaksanaan pelatihan yang dilakukan secara daring. Hal ini juga ditunjukkan oleh hasil penelitian terkait hambatan dalam pelaksanaan pendidikan daring yaitu kurangnya interaksi dengan peserta dan kelas, kesulitan dalam penggunaan teknologi (termasuk jaringan), dan kurangnya pengawasan pada peserta (Lloyd et al., 2012).

Terlepas dari hambatan yang dihadapi, hasil analisis statistik menunjukkan bahwa terdapat perbedaan skor pengetahuan peserta yang signifikan sebelum dan sesudah pelatihan diberikan dengan rerata gained score 1 poin. Hal ini berarti hipotesis penelitian ini diterima, yaitu terdapat perubahan signifikan literasi kesehatan mental pada peserta setelah diberikan pelatihan konselor sebaya daring. Perubahan skor peserta ini cukup bervariasi, di mana ada yang mengalami peningkatan hingga 3 poin, ada lima yang tetap, dan ada satu yang justru menurun skornya pada postes yaitu pada subjek SF.

Komponen lain dalam literasi kesehatan mental adalah keterampilan menolong diri sendiri dan orang lain yang dalam hal ini diwujudkan dalam bentuk roleplay konseling. Berdasarkan hasil observasi keterampilan konseling, dapat dilihat bahwa sebagian besar peserta cukup mampu menunjukkan keterampilan konseling misalnya mendengarkan, menunjukkan empati, juga menggunakan intonasi suara yang sesuai dengan cerita temannya yang bercerita. Di sisi lain ada empat peserta yang tampaknya masih kaku dalam mempraktikkan keterampilan konseling, di mana mereka belum dapat menggunakan intonasi suara yang tepat, kurang menghayati cerita klien, dan bahkan agak kurang serius. Meskipun demikian, berdasarkan hasil kuesioner evaluasi setelah pelatihan, dapat diketahui bahwa peserta mempersepsi adanya perubahan pengetahuan mereka terkait cara menolong diri sendiri maupun orang lain saat mengalami masalah psikologis. Hal ini juga didapatkan oleh hasil penelitian di Indonesia terkait pelatihan konselor sebaya pada siswa SMA, di mana terdapat berdasarkan hasil observasi terlihat adanya perubahan keterampilan konseling seperti mendengarkan, meringkas, bertanya, dan lain sebagainya setelah pelatihan konselor sebaya (Rahmawati et al., 2019).

Berdasarkan pemaparan di atas, hasil penelitian ini menunjukkan bahwa terdapat peningkatan literasi kesehatan mental pada peserta melalui pelatihan konselor sebaya, yang dapat dilihat melalui peningkatan signifikan skor literasi kesehatan mental pada postes, 
hasil observasi keterampilan konseling dasar, dan kuesioner evaluasi setelah pelatihan. Hasil penelitian ini juga didukung oleh beberapa hasil penelitian sebelumnya di mana program berbasis sekolah dan pelatihan konselor sebaya dapat meningkatkan literasi kesehatan mental. Penelitian pada siswa SMP selama tiga hari mampu meningkatkan pengenalan gejala gangguan psikologi, menurunkan stigma negatif terhadap kesehatan mental, dan meningkatkan pengetahuan di mana dapat mencari bantuan psikologis (Skre et al., 2013). Lebih lanjut, hasil penelitian di Amerika Serikat dengan subjek remaja menunjukkan bahwa intervensi untuk peningkatan literasi kesehatan mental berbasis kluster sekolah mampu meningkatkan literasi kesehatan mental pada masa follow up, meski tidak dapat menurunkan stigma terhadap gangguan jiwa (Pinto-Foltz et al., 2011). Penelitian terkait pelatihan konselor sebaya yang juga dilakukan secara daring, yaitu berbasis web juga ditemukan dapat meningkatkan keterampilan konseling peserta dan meningkatkan kemampuan mengenali gejala gangguan psikologis (Bernecker et al., 2020).

Pelatihan konselor sejatinya berbeda dengan pelatihan pendidikan pada umumnya karena merupakan kombinasi atas teori, pengetahuan, pengembangan keterampilan, kesadaran personal, dan refleksi (Hall, 2016). Seperti dijelaskan di atas terjadi perdebatan terkait dengan efektivitas pelatihan daring terutama kaitannya dengan meningkatkan keterampilan praktik psikologis seperti konseling. Namun demikian, pengembangan pelatihan maupun bentuk intervensi dalam bentuk daring sepertinya tidak terelakkan karena terjadinya pandemi COVID-19 yang tidak memungkinkan untuk melakukan tatap muka. Penelitian ini setidaknya dapat menjadi gambaran awal yang menunjukkan bahwa pelatihan secara daring memungkinkan untuk dilakukan dan memberikan hasil yang diharapkan.

Kelemahan dalam penelitian ini adalah pertama, desain eksperimen yang tidak disertai dengan kelompok kontrol karena sulitnya mencari peserta yang bersedia mengikuti pelatihan baik dari faktor internal (kesediaan meluangkan waktu) maupun keterjangkauan (terkait kepemilikan alat komunikasi yang memadai dan kesulitan jaringan), sehingga hasil yang didapatkan kelompok eksperimen tidak bisa dibandingkan dengan kelompok kontrol. Kedua, karena dilaksanakan secara daring maka peneliti tidak dapat mengamati secara langsung bagaimana respon dan ekspresi peserta selama pelatihan berlangsung, termasuk tidak bisa mengawasi saat peserta mengisi pre dan postes. Ketiga, jumlah partisipan dalam penelitian ini masih cukup terbatas yaitu hanya 16 orang siswa dan dilakukan pada sekolah dengan karakteristik khusus (swasta Islam), sehingga hasilnya mungkin belum dapat digeneralisasikan pada populasi yang lebih luas.

\section{Kesimpulan}

Hasil penelitian ini menunjukkan bahwa pelatihan konselor sebaya daring mampu meningkatkan literasi kesehatan mental peserta yang dapat dilihat melalui adanya peningkatan signifikan pada skala literasi kesehatan mental. Terdapat beberapa hambatan yang terjadi dalam proses pelatihan ini terkait dengan interaksi antara fasilitator dan 
peserta, juga terkait hal teknis seperti koneksi internet yang tidak stabil. Hasil ini memberikan gambaran bahwa pelatihan konselor dengan subjek siswa SMA memungkinkan diadaptasi untuk dilakukan secara daring dan memberikan hasil yang sesuai harapan. Meskipun demikian, hasil penelitian ini belum dapat digeneralisasikan karena terbatasnya jumlah partisipan dan adanya ancaman validitas internal karena belum adanya kelompok kontrol dalam desain eksperimen ini.

\section{Saran}

Untuk penelitian selanjutnya, disarankan untuk melakukannya dengan kelompok kontrol agar menghasilkan data yang lebih valid serta akurat. Kedua, disarankan untuk menjalin rapport dengan lebih baik dengan peserta sebelum pelatihan dilaksanakan, misalnya membuat kegiatan pre sesi yang lebih interaktif. Ketiga, materi dapat diusahakan seinteraktif mungkin dengan meminta peserta memberikan respon sehingga peserta merasa lebih terlibat di dalamnya. Keempat, menambahkan partisipan dan melakukannya dalam konteks sekolah yang berbeda, misalnya di sekolah negeri yang mungkin lebih mewakili populasi umum masyarakat.

\section{Kepustakaan}

Abdi, F., \& Simbar, M. (2013). The peer education approach in adolescents. Iranian Journal of Public Health, 42(11), 1200-1206.

Adedoyin, O. B., \& Soykan, E. (2020). Covid-19 pandemic and online learning: the challenges and opportunities. Interactive Learning Environments, 0(0), 1-13. https://doi.org/10.1080/10494820.2020.1813180

Al-Masyhida, J. W. Q. (2017). Pengaruh pelatihan "S3EHATI" terhadap literasi kesehatan jiwa dan keterampilan konseling dasar pada peer counsellor (Skripsi tidak dipublikasikan). Universitas Gadjah Mada.

Astiti, S. P. (2019). Efektivitas konseling sebaya (peer counseling) dalam menuntaskan masalah siswa. IJIP: Indonesian Journal of Islamic Psychology, 1(2), 243-263. https://doi.org/10.18326/ijip.v1i2.243-263

Badan Penelitian dan Pengembangan Kesehatan Kementerian Kesehatan RI. (2018). Riset kesehatan dasar.

Basoffi, M. (2018). Laporan magang bidang pendidikan di SMA Islam Sultang Agung 3 Semarang (Manuskrip tidak terpublikasi).

Bell, B. S., \& Federman, J. E. (2013). E-learning in postsecondary education. Future of Children 23(1), 165-185). https://doi.org/10.1353/foc.2013.0007

Bernecker, S. L., Williams, J. J., Caporale-Berkowitz, N. A., Wasil, A. R., \& Constantino, M. J. (2020). Nonprofessional peer support to improve mental health: Randomized trial of a scalable web-based peer counseling course. Journal of Medical Internet Research, 22(9), e17164. https://doi.org/10.2196/17164 
Campos, L., Dias, P., Duarte, A., Veiga, E., Dias, C. C., \& Palha, F. (2018). Is it possible to "Find space for mental health" in young people? Effectiveness of a school-based mental health literacy promotion program. International Journal of Environmental Research and Public Health, 15(7), 1-12. https://doi.org/10.3390/ijerph15071426

Dhawan, S. (2020). Online learning: A panacea in the time of COVID-19 crisis. Journal of Educational Technology Systems, 49(1), 5-22. https://doi.org/10.1177/0047239520934018

Fitri, R. S. (2019). Laporan magang Bidang Pendidikan di SMA Islam Sultan Agung 3 Semarang (Manuskrip tidak terpublikasi).

Gaytan, J., \& McEwen, B. C. (2007). Effective online instructional and assessment strategies. The American Journal of Distance Education, 21(1), 117-132. https://doi.org/10.1080/08923640701341653

Gray, H. D., \& Tindall, J. A. (1979). Peer counseling in-depth look at training peer helpers. Accelerated Development.

Gulliver, A., Griffiths, K. M., \& Christensen, H. (2010). Perceived barriers and facilitators to mental health help-seeking in young people: a systematic review. BMC Psychiatry, 113(10), 9. https://doi.org/10.1186/1471-244X-10-113

Hall, D. (2016). Online counselor training: Challenges and successes in the experiences of online counselor educators. University of North Carolina Greensboro.

Jorm, A. F. (2012). Mental health literacy: Empowering the community to take action for better mental health. American Psychologist, 67(3), 231-243. https://doi.org/10.1037/a0025957

Kalkbrenner, M. T., Sink, C. A., \& Smith, J. L. (2020). Mental health literacy and peer-to-peer counseling referrals among community college students. Journal of Counseling $\mathcal{E}$ Development, 98(2), 172-182. https://doi.org/https://doi.org/10.1002/jcad.12311

Kelly, C. M., Jorm, A. F., \& Wright, A. (2007). Improving mental health literacy as a strategy to facilitate early intervention for mental disorders. The Medical Journal of Australia, 187(7 Suppl), 1-5.

Kessler, R., Angermeyer, M., Anthony, J., De Graaf, R., Demyttenaere, K., Gasquet, I., De Girolamo, G., Gluzman, S., Gureje, O., Haro, J., Kawakami, N., Karam, A., Levinson, D., Medina, M. M., Oakley Browne, M., Posada-Villa, J., Stein, D., Adley Tsang, C., Aguilar-Gaxiola, S., ... Ustün, B. T. (2007). Lifetime prevalence and age-of-onset distributions of mental disorders in the World Health Organization's World Mental Health Survey Initiative. World Psychiatry, 6, 168-176.

Lloyd, S. a, Byrne, M. M., \& Mccoy, T. S. (2012). Faculty perceived barriers of online education. Journal of Online Learning and Teaching, 8(1), 1-12.

Maguire, S., Li, A., Cunich, M., \& Maloney, D. (2019). Evaluating the effectiveness of an evidence-based online training program for health professionals in eating disorders. Journal of Eating Disorders, 7(1), 1-11. https://doi.org/10.1186/s40337-019-0243-5

Marks, R. B., Sibley, S. D., \& Arbaugh, J. B. (2005). A Structural Equation Model of predictors for effective online learning. Journal of Management Education, 29(4), 531-563. https://doi.org/10.1177/1052562904271199 
Murdock, J., Williams, A., Becker, K., \& Bruce, M. A. (2012). Online versus on-campus: a comparison study of counseling skills courses. Journal of Human Resource and Adult Learning, 8(1), 105-118.

Patalay, P., Annis, J., Sharpe, H., Newman, R., Main, D., Ragunathan, T., Parkes, M., \& Clarke, K. (2017). A pre-post evaluation of OpenMinds: A sustainable, peer-led mental health literacy programme in universities and secondary schools. Prevention Science, 18(8), 995-1005. https://doi.org/10.1007/s11121-017-0840-y

Paul, G., Wendy, S., Denise, H., \& Clare, W. J. (2017). Examining mental health literacy, help seeking behaviours, and mental health outcomes in UK university students. Journal of Mental Health Training, Education and Practice, 12(2), 111-120. https://doi.org/10.1108/JMHTEP-05-2016-0027

Pinto-Foltz, M. D., Logsdon, M. C., \& Myers, J. A. (2011). Feasibility, acceptability, and initial efficacy of a knowledge- contact program to reduce mental illness stigma and improve mental health literacy in adolescents. Social Science \& Medicine, 72(12), 2011-2019. https://doi.org/10.1016/j.socscimed.2011.04.006

Rahmawati, A., Suwarjo, \& Utomo, H. B. (2019). The effect of basic skills counseling as vital skills in peer counseling to Indonesian students. Universal Journal of Educational Research, 7(9), 1874-1881. https://doi.org/10.13189/ujer.2019.070905

Reavley, N. J., McCann, T. V., \& Jorm, A. F. (2012). Mental health literacy in higher education students. Early Intervention in Psychiatry, 6(1), 45-52. https://doi.org/10.1111/j.1751-7893.2011.00314.x

Ridha, A. A. (2019). Penerapan konselor sebaya dalam mengoptimalkan fungsi layanan bimbingan konseling di sekolah. Jurnal Psikologi, 15(1), 25. https://doi.org/10.24014/jp.v15i1.6549

Risnawaty, W., Kartasasmita, S., \& Suryadi, D. (2019). Pelatihan Konselor Sebaya pada Siswa SMA di Jakarta Barat Peer. MITRA: Jurnal Pemberdayaan Masyarakat, 3(2), 108-119. https://doi.org/10.25170/mitra.v3i2.350

Roth, G., Jacob, C. J., Stoler, J. R., \& Oloidi, W. (2019). Learning to be a counselor at a distance: A qualitative investigation of the distance education experience for counselors-in-training. Journal of Counselor Preparation and Supervision, 12(3). Diakses melalui https://repository.wcsu.edu/jcps/vol12/iss3/2

Salmiati, S., Hasbahuddin, H., \& Bakhtiar, M. I. (2018). Pelatihan konselor sebaya sebagai strategi pemecahan masalah siswa. MATAPPA: Jurnal Pengabdian Kepada Masyarakat, 1(1), 36. https://doi.org/10.31100/matappa.v1i1.117

Setiawan, A. R., Puspaningrum, M., \& Umam, K. (2019). Pembelajaran fiqh mu'āmalāt berorientasi literasi finansial. TARBAWY: Indonesian Journal of Islamic Education, 6(2), 187-192. https://doi.org/10.17509/t.v6i2.20887

Skre, I., Friborg, O., Breivik, C., Johnsen, L. I., Arnesen, Y., Elisabeth, C., \& Wang, A. (2013). A school intervention for mental health literacy in adolescents: Effects of a nonrandomized cluster controlled trial. BMC Public Health, 13, 873. https://doi.org/10.1186/1471-2458-13-873 
Smith, C. L., \& Shochet, I. M. (2011). The impact of mental health literacy on help-seeking intentions: Results of a pilot study with first year psychology students. International Journal of Mental Health Promotion, 13(2), 14-20. https://doi.org/10.1080/14623730.2011.9715652

Suwarjo. (2008). Konseling teman sebaya (peer counseling) untuk mengembangkan resiliensi remaja. Seminar Ilmu Pendidikan Fakultas Ilmu Pendidikan Universitas Negeri Yogyakarta, 1-16.

Tindall, J. A. (2009). Peer power (Book One). Routledge.

Titisari, N., Yusmansyah, \& Oktariana, Y. (2019). Penggunaan konseling sebaya mengurangi konformitas negatif siswa. ALIBKIN Jurnal Bimbingan Konseling, 7(4).

World Health Organization. (2020). Adolescent mental health. World Health Organization. https://doi.org/10.1037/0003-066X.44.2.200

Zamroni, E., \& Masturi, M. (2017). Pelatihan peer counseling pada remaja di Panti Sosial Asuhan Anak (PSAA) Tunas Bangsa Pati. Bagimu Negeri: Jurnal Pengabdian Kepada Masyarakat, 1(1).

\section{Wawancara}

Guru Bimbingan Konseling. (10 Agustus 2020). Wawancara Awal Permasalahan SMA Islam XY. (D. U. Syafitri, Interviewer)

Siswa A. (12 Agustus 2020). Wawancara Awal Permasalahan SMA Islam XY. (D. U. Syafitri, Interviewer)

Siswa B. (12 Agustus 2020). Wawancara Awal Permasalahan SMA Islam XY. (D. U. Syafitri, Interviewer)

Wakil Kepala Sekolah. (11 Agustus 2020). Wawancara Awal Permasalahan SMA Islam XY. (D. U. Syafitri, Interviewer) 